\title{
Safety of Mosul and Haditha Dams, West Iraq as Affected by Karstification
}

\author{
Varoujan K. Sissakian', Nadhir Al-Ansari' ${ }^{2}$, Nasrat Adamo ${ }^{3}$, Jan Laue ${ }^{2}$ \\ ${ }^{1}$ Department of Natural Resources Engineering and Management, University of Kurdistan Hewler, Erbil, Iraq \\ ${ }^{2}$ Department of Civil, Environmental and Natural Resources Engineering, Lulea University of Technology, Lulea, Sweden \\ ${ }^{3}$ Norrköping, Sweden \\ Email: f.khajeek@ukh.edu.krd, varoujan49@yahoo.com,nadhir.alansari@ltu.se,nasrat.adamo@gmail.com, jan.leaue@ltu.se
}

How to cite this paper: Sissakian, V.K., Al-Ansari, N., Adamo, N. and Laue, J. (2022) Safety of Mosul and Haditha Dams, West Iraq as Affected by Karstification. Open Journal of Geology, 12, 1-12. https://doi.org/10.4236/ojg.2022.121001

Received: December 3, 2021

Accepted: January 9, 2022

Published: January 12, 2022

Copyright $\odot 2022$ by author(s) and Scientific Research Publishing Inc. This work is licensed under the Creative Commons Attribution International License (CC BY 4.0).

http://creativecommons.org/licenses/by/4.0/

\begin{abstract}
Mosul and Haditha dams are two large earthfill dams in Iraq constructed on the Tigris and Euphrates rivers, respectively. The two dams were constructed almost at the same period in the mid-eighties of the last century. Both dams suffer from karstification within their foundations. In the former, however, the problem is more severe than the latter. Mosul Dam was constructed on karstified gypsum and limestone beds; different grouting techniques were used, but the works in grouting are still going on to keep the dam as safe as possible as the sealing of the foundation is hampered by the type of geology. Haditha Dam was constructed on karstified limestone and gypsum rocks also. To avoid the effect of the karstification on the safety of this dam, an exceptionally long grout curtain was constructed as foundation treatment work. The length of the grout curtain extended under the earthfill dam and the concrete structures in the river channel and extended beyond the abutments forming left and right sides extensions to cut off water percolation around the dam which could cause the formation of sinkholes. The depths of all parts of the curtain varied following the karstification zones and intensities. The details of both dams are discussed using updated data and relying on the experience of the authors. The current status of both dams is also discussed with some recommendations to keep both dams as safe as possible.
\end{abstract}

\section{Keywords}

Karstification, Mosul Dam, Haditha Dam, Grouting, Dissolution, Gypsum, Limestone 


\section{Introduction}

The Mosul and Haditha dams are two large earthfill dams constructed on the Tigris and Euphrates rivers in the western part of Iraq (Figure 1). The two dams are the largest in Iraq, the storage capacities of the Mosul and Haditha dams are $11.11 \times 10^{9} \mathrm{~m}^{3}$, and $6.4 \times 10^{9} \mathrm{~m}^{3}$, respectively [1]. Both dams suffer from severe karstification problems [1] [2] [3] [4]. The karstification in the foundation of the Mosul Dam is mainly in the highly karstified gypsum beds of the Fatha Formation, whereas, in the foundations of the Haditha Dam it is related to the highly karstified limestone beds of the Euphrates Formation [1]. Grouting was performed systematically in both dams during the construction; however, in the Mosul Dam; it is still a continuous and ongoing process until now [4].

Tens of published articles and scientific reports concerning different aspects related to the Mosul and Haditha dams were reviewed in order to conduct the current study (e.g. [1] [2] [3] [4]). Besides, many visits were made to both dam sites during different periods, which started from the times of the sites' studies during mid-seventies of the last century until early 2021, separately by the authors.

The aim of this study is to elucidate the impacts of karstification on the safety of the two dams and its effects on the designs of both. The study is based on the most updated necessary data.

\section{Geological Setting}

The geological setting of the Mosul and Haditha dams are briefed hereinafter

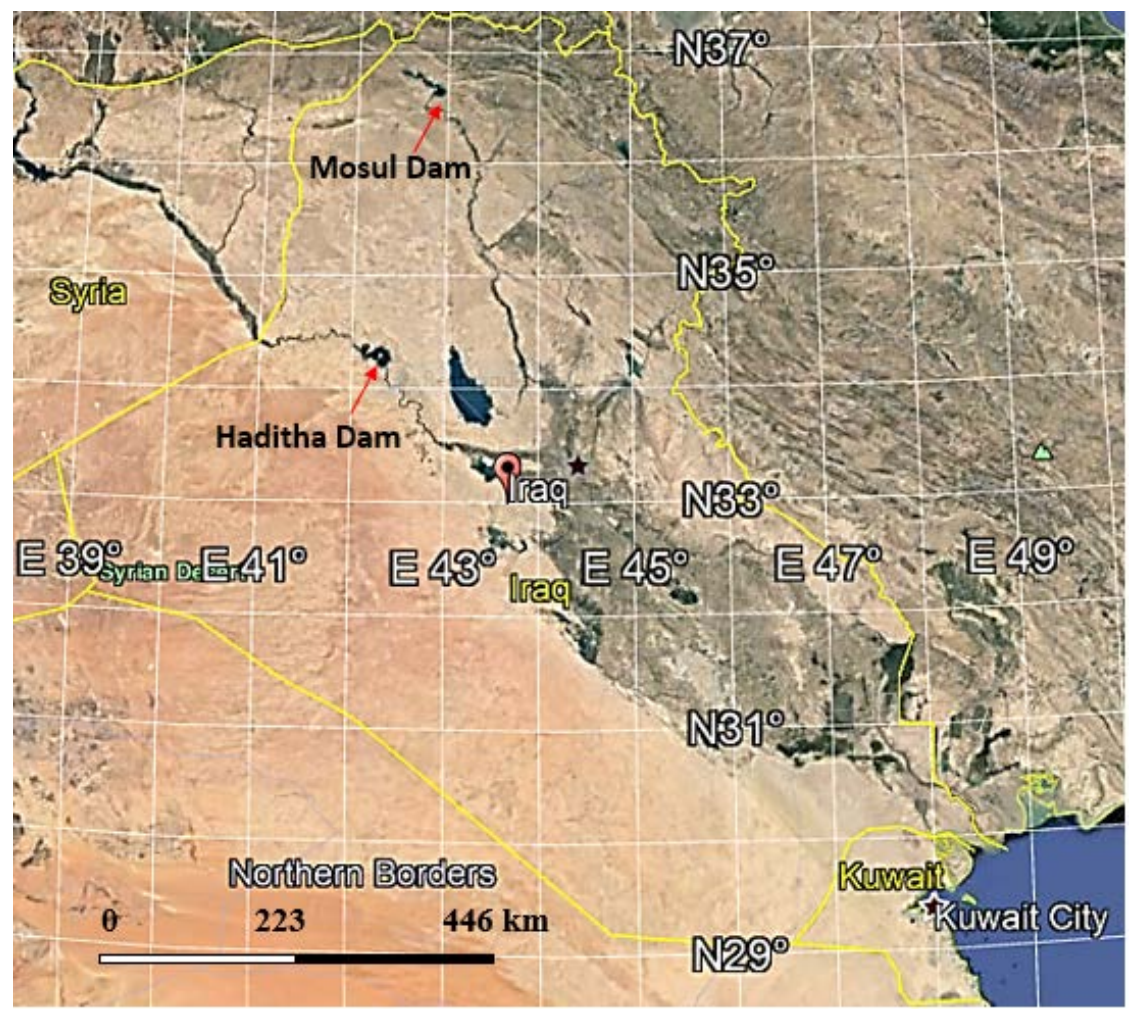

Figure 1. Satellite image showing location of the Mosul and Haditha dams. 
based on Sissakian and Fouad [5].

\subsection{Mosul Dam}

The Mosul Dam is located tectonically within the Low Folded Zone of Iraq that is resulted due to the collision of the Arabian and Eurasian plates in convergent plate tectonic type [6] [7]. The exerted forces from the collision have formed low amplitude anticlines with NW-SE trend; among them is Butmah anticline where the Mosul Dam is located at its southeastern plunge. Few faults of different types and sizes have developed too; their main effect on the dam is increasing the fracturing system, which in terms has increased the dissolution ability of the karstified rocks at the foundation and site of the dam.

The exposed formation in the dam site and majority of the reservoir area is the Fatha Formation (Figure 2). The formation consists of cyclic deposits, each cycle consists of green marl, limestone, and gypsum; however, in the upper parts, reddish brown claystone occurs in the cycles. The gypsum beds are severely karstified (Figure 3) causing the main problem in the dam's foundation.

The main geomorphological forms in the dam site are the karstification, the sinkholes being the main form at different sizes and forms, as appeared on the surface (Figure 4) and/or at subsurface (Figure 3).

The sinkhole shown in Figure 4 was developed downstream, near the touristic city at the dam site after filling of the reservoir. The authorities of the dam have filled the sinkhole in an attempt to block it, but after two years, the sinkhole was found empty from the dumped materials.

\subsection{Haditha Dam}

The Haditha Dam is located tectonically in the Inner Platform (Stable Shelf) [7],

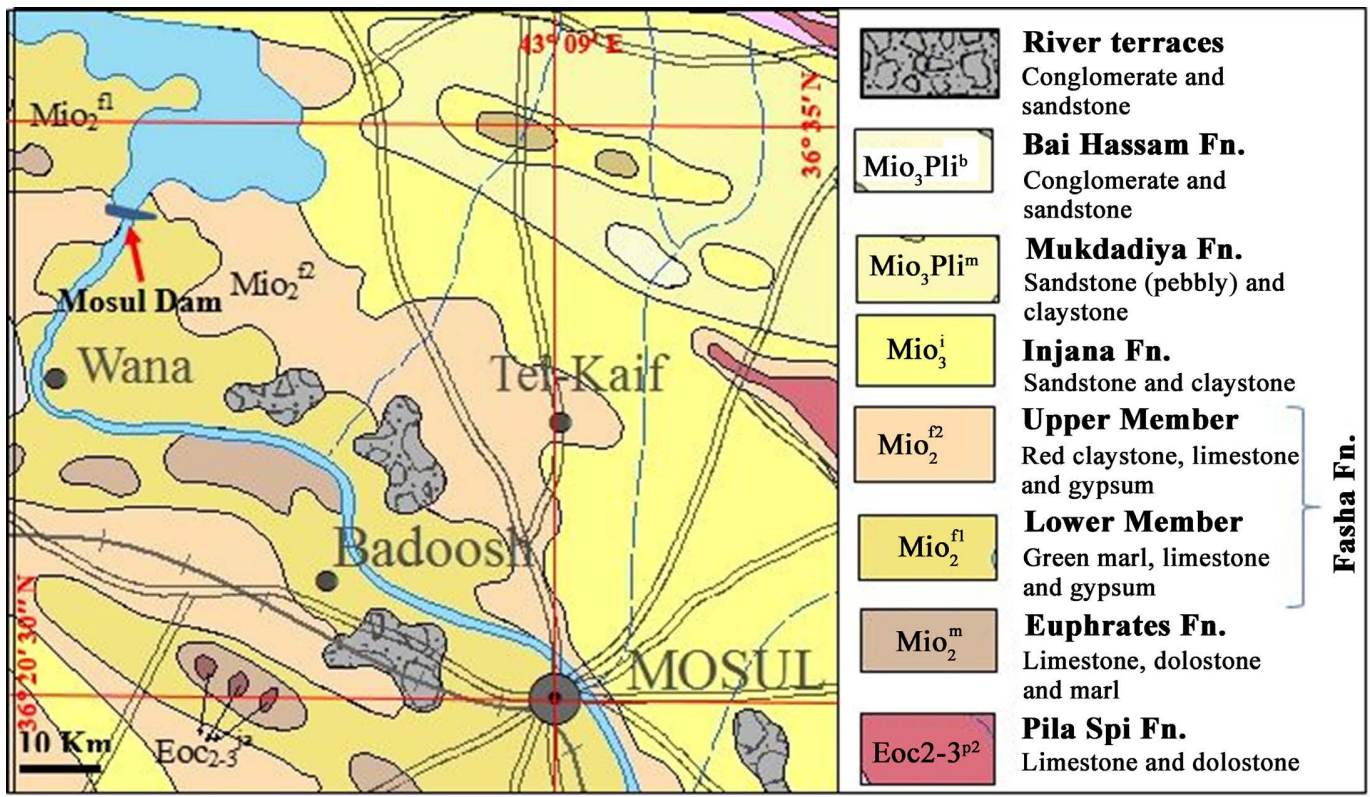

Figure 2. Geological map of the Mosul dam site and reservoir area (From [5]). 


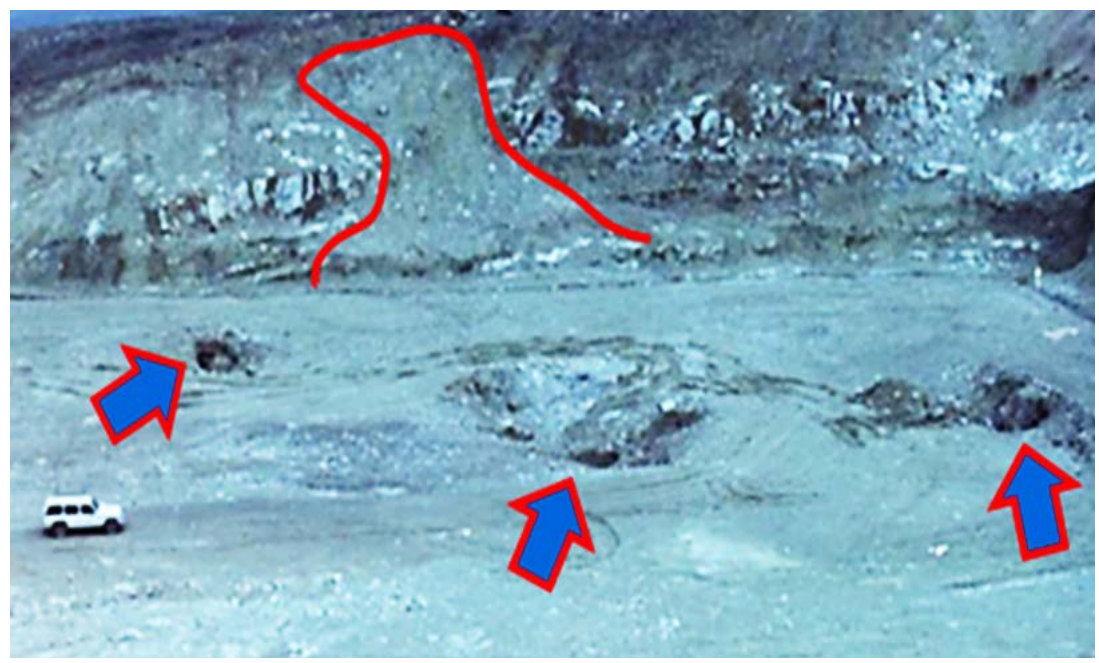

Figure 3. A karstified site, $15 \mathrm{~km}$ southeast of Mosul Dam, note the karstified gypsum beds (white color) and their total absence in the limited area by the red line (due to dissolution), and the developed sinkholes in the ground (After [8]).

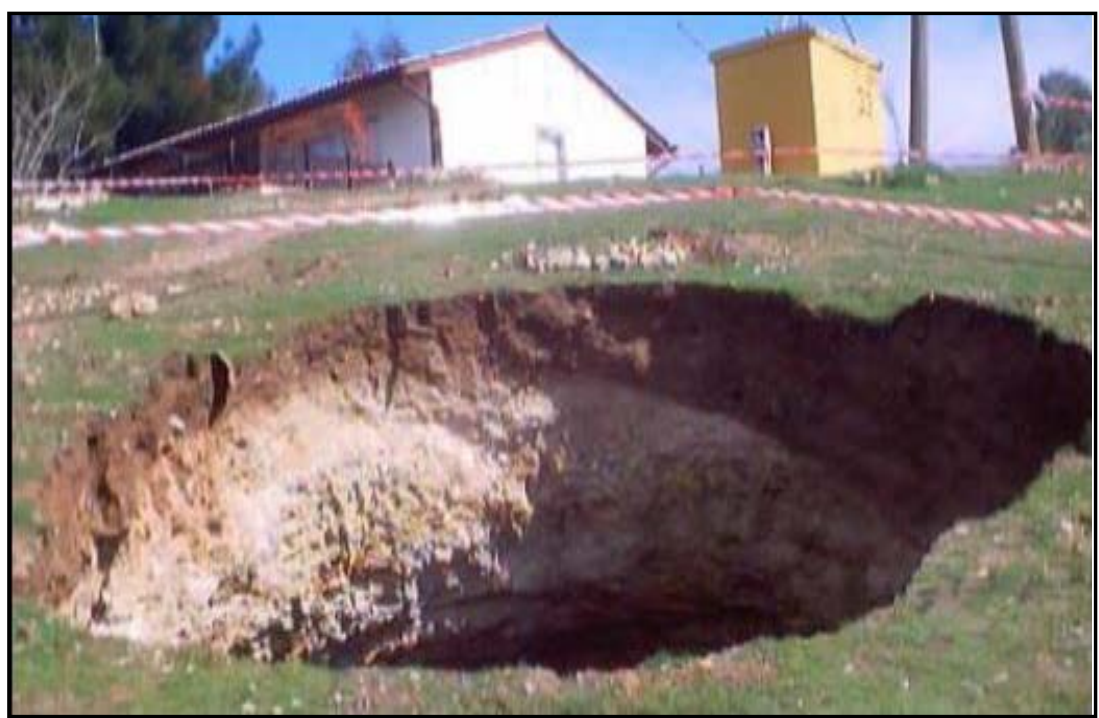

Figure 4. A sinkhole which was developed downstream after filling the reservoir (15 February 2015)

which means that there are no tectonic forces effecting on the dam site. However, the exposed rocks suffer from severe undulations, jointing and fracturing indicating that the rocks have dealt with forces developed due to old earthquakes during the deposition, burial duration, and before being lithified [9].

The exposed formation at the Haditha Dam site and majority of the reservoir area belong to the Euphrates and Fatha formations (Figure 5).

The Euphrates formation consists mainly of limestone, dolostone and dolomitic limestone with marl intercalations. The rocks of this formation suffer from severe karstification, the sinkholes being the main consequence. Different types and sizes of sinkholes are developed in the dam site; Sissakian et al. [10] have recognized 54 sinkholes at the dam site and near surroundings. The Fatha Formation 


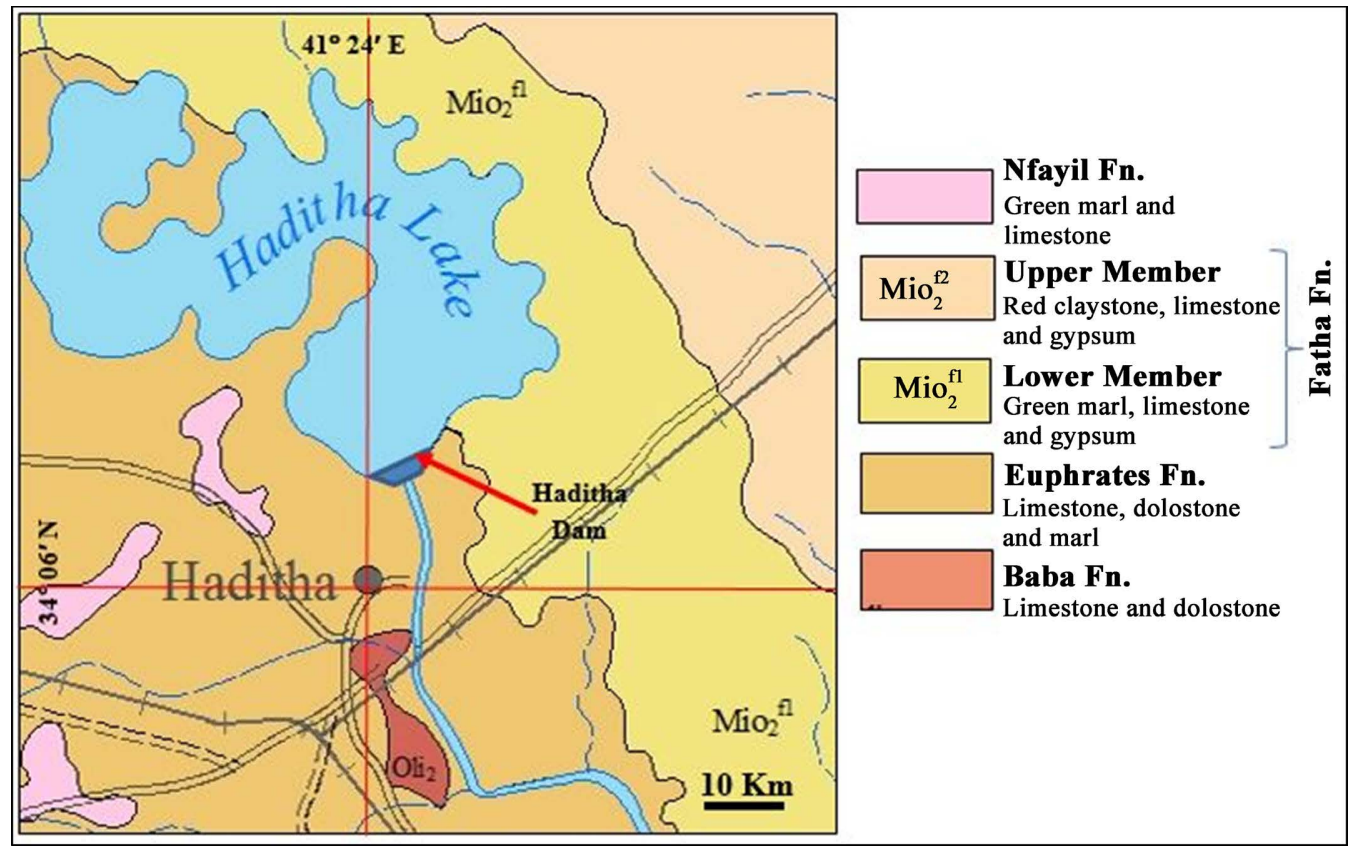

Figure 5. Geological map of the Haditha dam site (From [5]).

is exposed north of the Euphrates River (Figure 5), consists of cyclic deposits, each cycle consists of green marl, limestone, and gypsum; however, in the upper parts, reddish brown claystone occurs in the cycles.

\section{Results}

From reviewing and evaluating tens of relevant published articles and reports, which deal with the Mosul and Haditha dams, the following results have been reached.

\subsection{Mosul Dam}

The Mosul Dam is located at $80 \mathrm{~km}$ from the entry point of the Tigris River from Turkey to the Iraqi territory; $70 \mathrm{~km}$ northwest of the city of Mosul, which is about $410 \mathrm{~km}$ north of the capital Baghdad. The Mosul Dam is an earthfill dam; its length is $3400 \mathrm{~m}$, the width at the dam crest is $20 \mathrm{~m}$ while the maximum width at the base is $650 \mathrm{~m}$ at the deepest point in the river, whereas the maximum height is $113 \mathrm{~m}$ from the deepest point in the river channel. Therefore, the crest level of the dam was fixed at $341.6 \mathrm{~m}$ (a.s.l.). Normal and Maximum Operation Water levels are $330 \mathrm{~m}$ (a.s.l.) and $335 \mathrm{~m}$ (a.s.l.), respectively, whereas the Maximum Flood Water Level is $338 \mathrm{~m}$ (a.s.l.). The storage capacity is $11.11 \times 10^{9}$ $\mathrm{m}^{3}$ at elevation $330 \mathrm{~m}$ (a.s.l.) [11]. The cross section of the Mosul Dam is shown in Figure 6, where the clay core with filters, and sand gravel shell on both sides of the core can be seen.

\subsection{Haditha Dam}

The Haditha Dam is located about $130 \mathrm{~km}$ southeast of the entry point of the 
Euphrates River the Iraqi territory, near the Al-Qaim town. The Dam is located at about $270 \mathrm{~km}$ northwest of Baghdad and about $14 \mathrm{~km} \mathrm{NW}$ of the Haditha town (Figure 1). The Haditha Dam is an earthfill Dam; its length is $9064 \mathrm{~m}$, the width at the dam crest is $40 \mathrm{~m}$, while the maximum dam base width is more than $200 \mathrm{~m}$ depending on riverbed elevation, and the maximum height is $57 \mathrm{~m}$ from the deepest point at the river channel and dam crest level is $154.00 \mathrm{~m}$ (a.s.l.). The Normal and Maximum Operation Water levels are $143 \mathrm{~m}$ (a.s.l.) and $147 \mathrm{~m}$ (a.s.1.), respectively. The Maximum Flood Water Level is $152.2 \mathrm{~m}$ (a.s.1.). The storage capacity is $6 \times 10^{9} \mathrm{~m}^{3}$ at elevation $143 \mathrm{~m}$ (a.s.l.) [11]. The cross section of the dam is shown in Figure 7, which is quite different from that of the Mosul Dam. The main reason for this difference is the absence of the suitable amount of clay to be used in the core. Therefore, dolomite rocks were powdered and used in the core instead of the clay. Another reason is that the foundation of the dam is located on the limestone beds of the lowermost part of the Euphrates Formation, which are less karstified as compared to the gypsum rocks at the foundation of the Mosul Dam.

\subsection{The Role of Karstification in the Safety of the Mosul and Haditha Dams}

Both sites of the Mosul and Haditha dams are highly karstified [1] [3] [5] [8] [12]. Therefore, special foundation treatments were prescribed in the designs of both dams in their foundations and body of the dam [4] [11] [13].

\subsubsection{Karstification in Mosul Dam}

The Mosul Dam site and large extent of the reservoir area located within the Fatha

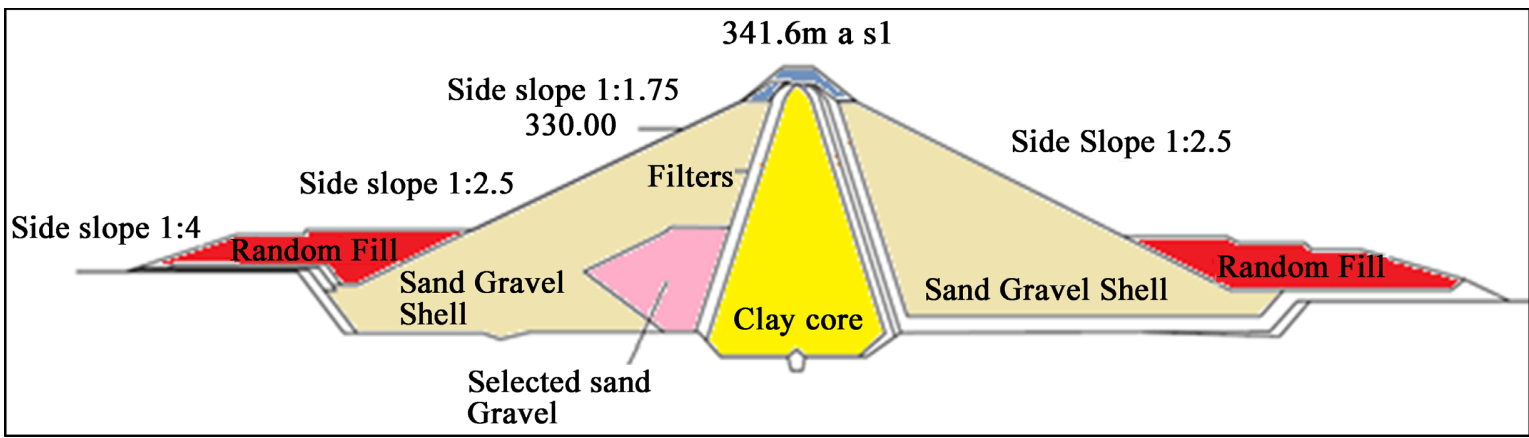

Figure 6. Cross section in the Mosul Dam (After [11]).

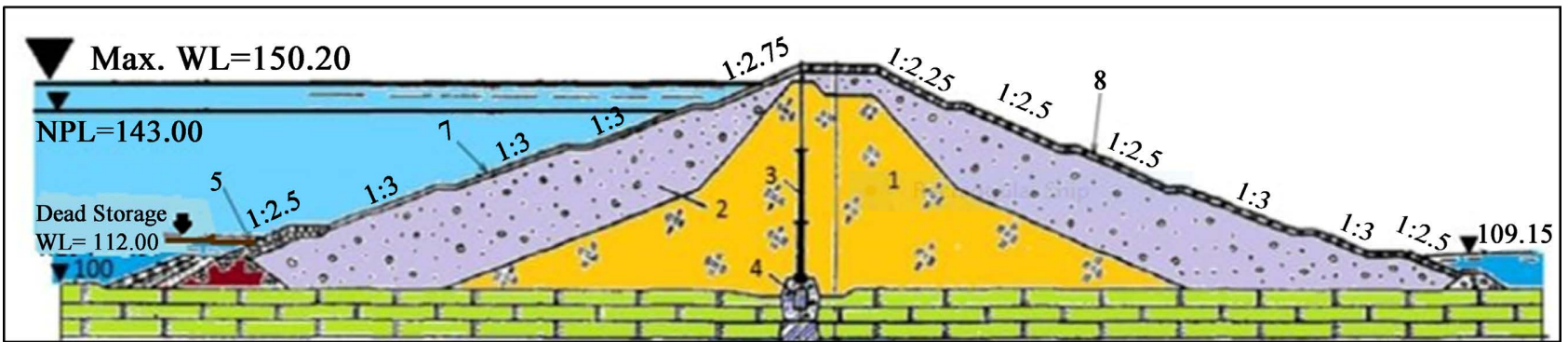

Figure 7. Cross section in the Haditha Dam (After [11]). 
Formation (Middle Miocene age) [5] [14] (Figure 2). The gypsum beds in the Fatha Formation are highly karstified, and locally they are totally dissolved leaving voids of different shapes and sizes (Figure 3), which are filled by weathered materials from the overlying beds; like gypsiferous clayey soil, limestone, and gypsum fragments [9] [14].

\subsubsection{Karstification in Haditha Dam}

The Haditha Dam site and the southern bank of the reservoir area are within the Euphrates Formation (Lower Miocene age), the northern bank of the reservoir; however, and the left abutment are within the Fatha Formation (Middle Miocene age) [5] [14] (Figure 5). The Euphrates Formation in the dam site is underlain by the Anah Formation (Upper Oligocene age), and the karstification is noted to be more extensive when the Anah Formation is exposed, especially in deeply cut valleys near the dam site, with thick Terra Rossa sediments above the basal conglomerate [8] [10] [14]. To avoid the effect of the karstification on the safety of this dam, an exceptionally long grout curtain was constructed as foundation treatment work as explained in the discussion

\section{Discussion}

In the following, the roles of the karstification on the safety of the Mosul and Haditha dams are discussed. The effects of the karstification and the considered treatments in the foundations and the dam body are discussed too.

\subsection{Treatments in Mosul Dam}

Due to the highly karstified gypsum beds of the Fatha Formation below the foundations of the dam, continuous grouting was carried out starting from the construction stage and has continued ever since as ongoing maintenance process [4]. Total maintenance grouting material quantities used since the end of the contractors' obligations in 1991 up to the end of 2018 has exceeded 210 thousand tons. One of the main reasons for continuous grouting is the miss-interpretation of the acquired data from the extracted cores of the drilled boreholes and the performed permeability tests [12]. Accordingly, the depths of the grouting boreholes were not determined correctly (Figure 8).

Many gypsum beds can still be seen below the constructed and assumed karstification line (Figure 8), and when grouting does not reach these gypsum beds, which are present below the assumed karstification line, then the dissolution of these beds continues due to the high head of the storage water in the reservoir and, the increased groundwater movement. This can be seen clearly from the type of the extracted core (Figure 9) where the rocks are in form of small pieces rather than to be in form of continuous masses. This is an excellent indication for the poor status of the rocks in the foundations of the Mosul Dam; therefore, the continuous grouting was not able to block permeability, the voids, and caverns, which are present in the rocks under the foundations. Another good indication for the activity of the karstification is the developed sinkhole in the touristic camp 
(Figure 4) at the dam site and the repeated attempts, which took two years to block the sinkhole, but all attempts were in vain. The other mistake was that the grout ability of the karstified gypsum which fills the dissolution cavities was misjudged and these pockets proved to be un-grout able, leaving open windows in the curtain. Moreover, the encountered Terra Rossa formation in the lower

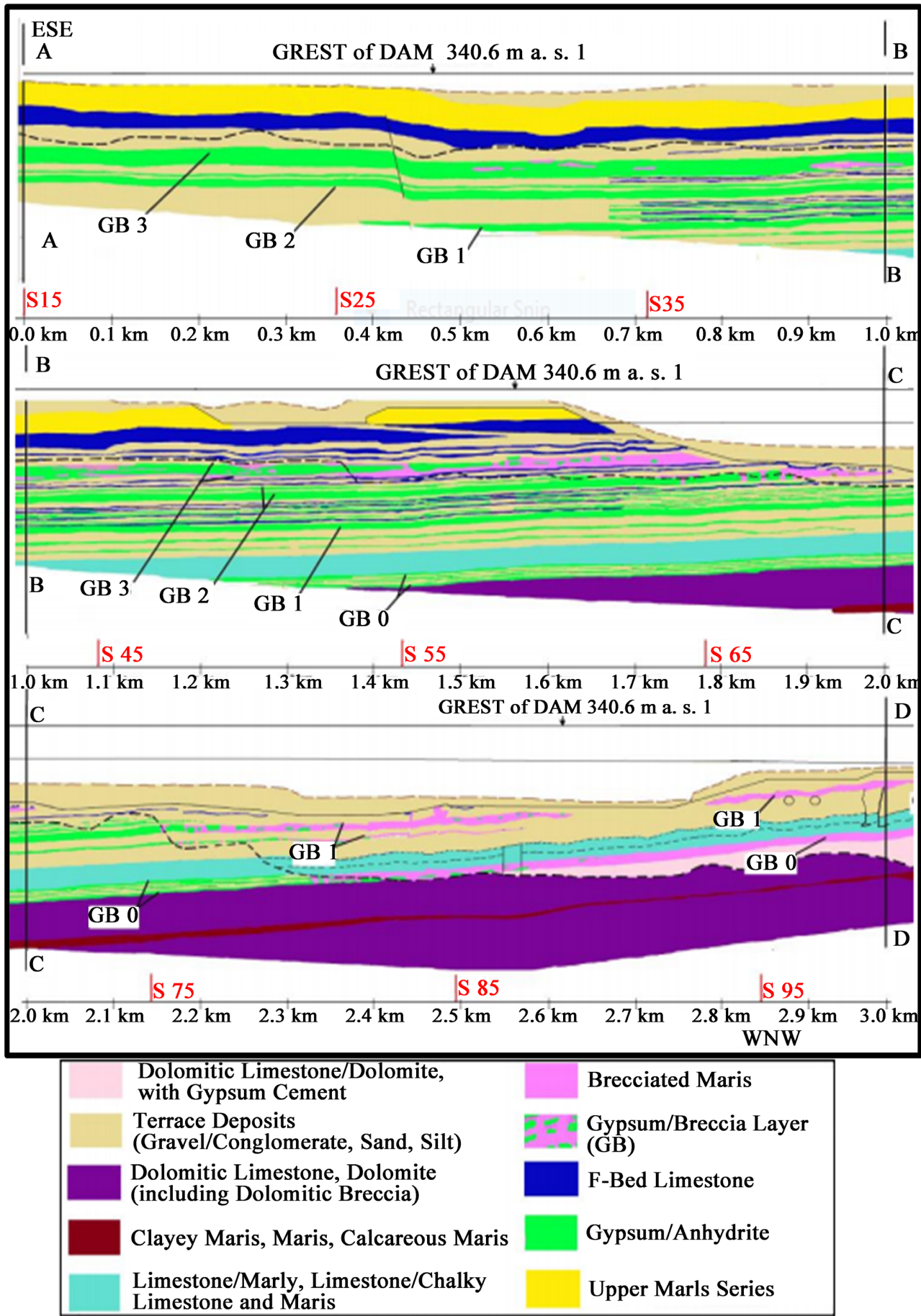

Figure 8. Geological cross sections along the Mosul Dam site. The dashed black line represents the karstified line. The grouting boreholes were drilled to the depth of the karstified line. Note the existing of gypsum beds below the karstified line (After [2]). 


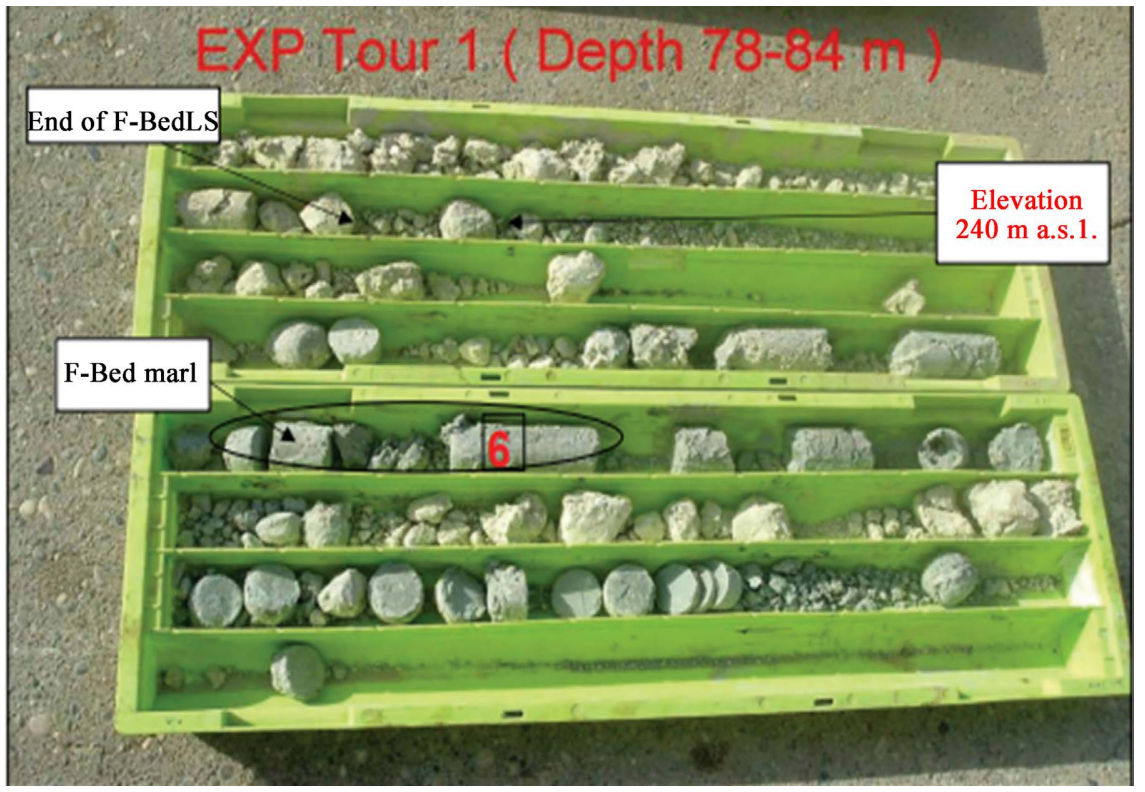

Figure 9. Part of the extracted core at the Mosul Dam Site. Note the poor RQD of the core.

levels of the foundation was described as bauxite [12], which, in fact, was good indication for karstification [15]. The grouting, itself, as can happen in certain cases, may cause certain problems instead of sealing the caverns initiated by karstification; such cases are well known world-wide [16] [17]. In Mosul Dam site, different grouting materials and mix types and techniques were used, but grouting is still necessary as a maintenance effort [11] [13]. It is worth mentioning that; despite the maximum operation water level of the reservoir has been reduced from $330 \mathrm{~m}$ (a.s.l.) to $319 \mathrm{~m}$ (a.s.l.) for the past sixteen years, this could not stop the problem, which means the Mosul Dam is not functioning as planned.

\subsection{Treatments in Haditha Dam}

The site of Haditha Dam and its surroundings suffer also from sever karstification. This is attributed to the exposed limestone beds of the Euphrates Formation on the right abutment and southern bank of the reservoir, and the exposed gypsum beds of the Fatha Formation on the left abutment. However, the karstification is more severe in the southern part and the dam site where the Euphrates Formation is exposed. This severe karstification with tens of sinkholes around the dam site [10] was treated by deep grout curtain [4] [18]. Such treatment during dam construction at karstified areas is common world-wide [19].

The length of grout curtain extended beyond the dam body of $9064 \mathrm{~m}$, covering the foundations of the concrete "powerhouse-spillway structure" in the river channel and having right and left banks extensions. The right bank extension is exceptionally long due to the extent of the sinkhole area in this bank, since some of the sinkholes has depths and widths of more than $50 \mathrm{~m}$ and $35 \mathrm{~m}$, respectively. The grout curtain under the earthfill embankment in the river section and 
abutments was done in two rows, while under the concrete structure it consisted of three rows of holes. The left bank extension, however, had two rows. Grouting in the right-side extension was performed in boreholes drilled at one meter spacing to reduce water penetration and movement around the flank of the dam and reduce dissolution and development of more sinkholes. In one of the grouting boreholes, about 500 tons of grouting materials were injected to cover the developed cavern below the drilled borehole, whereas normally 2 - 5 tons were used (from the field observations of the first author, 1984). Moreover, the dam authorities have estimated the water intake in a sinkhole, which is developed at the bottom of a large valley that drains in the Euphrates River near the dam site, to be $5000 \mathrm{~m}^{3}$ per hour. This is another indication of the ability of the movement of the groundwater as extremely high hydraulic coefficient of the rocks in the Haditha Dam site.

\section{Conclusion}

Since there are tens of published scientific papers and reports concerning the Mosul Dam safety; therefore, new conclusions on this dam are exceedingly rare. We can emphasize, however, that relying on modern inspection and grouting techniques and keeping vigil on Mosul Dam foundation conditions, with continuous maintenance grouting can help in preserving the dam's safety. When it comes to Haditha Dam, the good understanding of its foundation and its surrounding karstification during design stage, coupled with the constructed long curtain, with properly judged depths at its various parts, have resulted in that Haditha Dam is comparatively more stable than Mosul Dam. This can be confirmed by the continuous grouting at the Mosul Dam site, whereas at the Haditha Dam site is not anymore grouting, although the number of the existing sinkholes on the surface of the Hadith Dam site is more than those in the Mosul Dam site. However, the karstification in the foundations of the Mosul Dam is extremely higher than in the Haditha Dam, as indicated from the status of the extracted cores and other taken safety measures.

\section{Conflicts of Interest}

The authors declare no conflicts of interest regarding the publication of this paper.

\section{References}

[1] Sissakian, V.K., Adamo, N., Al-Ansari, N., Knutsson, S., Laue, J. and Elagely, M. (2018) A Comparative Study of Mosul and Hadithaa Dams, Iraq: Geological Conditions. Journal of Earth Sciences and Geotechnical Engineering, 8, 35-52.

[2] Al-Ansari, N., Adamo. N., Issa E.I., Sissakian, V.K. and Knutsson, S. (2015) Mystery of Mosul Dam the Most Dangerous Dam in the World: Karstification and Sinkholes. Journal of Earth Sciences and Geotechnical Engineering, 5, 33-45.

[3] Al-Ansari, N., Adamo, N., Sissakian, V., Sven, K. and Laue, J. (2017) Is Mosul Dam the Most Dangerous Dam in the World? Review of Previous Work and Possible So- 
lutions. Engineering, 9, 801-823. https://doi.org/10.4236/eng.2017.910048

[4] Adamo, N., Sissakian, V.K., Al-Ansari, N., Knutsson, S., Laue, J. and Elagely, M. (2018) Comparative Study of Mosul and Hadithaa Dams, Iraq: Foundation Treatments in the Two Dams. Journal of Earth Sciences and Geotechnical Engineering, 8 , 53-70.

[5] Sissakian, V.K. and Fouad, S.F. (2015) Geological Map of Iraq, Scale 1: 1000000, 4th Edition. Iraqi Bulletin of Geology and Mining, 11, 9-16.

[6] Alavi, M. (2004) Regional Stratigraphy of the Zagros Fold-Thrust Belt of Iran and Its Proforeland Evolution. American Journal of Science, 304, 1-20.

https://doi.org/10.2475/ajs.304.1.1

[7] Fouad, S.F. (2015) Tectonic Map of Iraq, Scale 1: 1000000, 3rd Edition, Iraqi Bulletin of Geology and Mining, 11, 1-7.

[8] Sissakian, V.K., Al-Ansari, N. and Knutson, S. (2014) Karstification Problems in Mosul Dam and Its Assessment, North Iraq. Engineering, 6, 82-94.

https://doi.org/10.4236/eng.2014.62012

http://www.scirp.org/journal/eng

[9] Sissakian, V.K., Fouad, S.F., Al-Ansari, N. and Knutsson, S. (2014) Deformational Style of the Soft Sediments (Seismites) within the Uppermost Part of the Euphrates Formation, West Iraq. Journal of Earth Sciences and Geotechnical Engineering, 4, 71-86.

[10] Sissakian, V.K., Ibrahim, A.M. and Amin, R.M. (1986) Sinkholes of Hadithaa Area. Journal of Water Resources, 5, 707-714.

[11] Adamo, N. and Al-Ansari, N. (2016) Mosul Dam the Full Story: Engineering Problems. Journal of Earth Science and Geotechnical Engineering, 6, 213-244.

[12] Sissakian, V., Adamo, N., Al-Ansari, N., Knutsson, S. and Laue, J. (2017) Defects in Foundation Design Due to Miss-Interpretation of the Geological Data: A Case Study of Mosul Dam. Engineering, 9, 683-702.

https://doi.org/10.4236/eng.2017.97042

[13] Adamo, N., Al-Ansari, N., Issa, E.I., Sissakian, V.K. and Knutsson, S. (2015) Mystery of Mosul Dam the most Dangerous Dam in the World: Problems Encountered During and after Impounding the Reservoir. Journal of Earth Sciences and Geotechnical Engineering, 5, 47-56.

[14] Sissakian, V., Al-Ansari, N., Issa, I., Adamo, N. and Knutsson, S. (2015) Mystery of Mosul Dam the Most Dangerous Dam in the World: General Geology. Journal of Earth Sciences and Geotechnical Engineering, 5, 1-13.

[15] Banerjee, A. and Merino, E. (2011) Terra Rossa Genesis by Replacement of Limestone by Kaolinite. III. Dynamic Quantitative Model. The Journal of Geology, 119, 259-274. https://doi.org/10.1086/659146

[16] Bonacci, O., Gottstein, S. and Roja-Bonacci, T. (2009) Negative Impacts of Grouting on the Underground Karst Environment. Echohydrology, 2, 492-502.

https://doi.org/10.1002/eco.90

[17] Bonacci, O. and Bonaci, T. (2013) The Possible Negative Consequences of Underground Dam and Reservoir Construction and Operation in Coastal Karst Areas: An Example of the Hydro-Electric Power Plant (HEPP) Ombla Near Dubrovnik (Croatia). Natural Hazards Earth System Sciences, 13, 2041-2052. https://doi.org/10.5194/nhess-13-2041-2013

[18] Sissakian, V., Adamo, N., Al-Ansari, N., Laue, J. and Knutsson, S. (2021) Hadithaa Dam and Karst Features, West Iraq. University of Kurdistan Hewler Scientific 
Journal, 5, 111-118. https://doi.org/10.25079/ukhjse.v5n1y2021.pp111-118

[19] Turkmen, S., Ozguler, E., Taga, H. and Karaogullariadan, T. (2002) Seepage Problems in the Karstic Limestone Foundation of the Kalecik Dam (South Turkey). Engineering Geology, 63, 247-257. https://doi.org/10.1016/S0013-7952(01)00085-0 